\title{
The concept of God: From the lens of students of integrated Islamic elementary schools
}

\author{
Reni Susanti ${ }^{1}$, Ikhwanisifa ${ }^{2}$ \\ ${ }^{1,2}$ Faculty of Psychology UIN Sultan Syarif Kasim Riau, Indonesia \\ ${ }^{1}$ reni.susanti@uin-suska.ac.id, ${ }^{2}$ ikhwanisifa@uin-suska.ac.id
}

\section{ARTICLE INFO}

Article history

Received 12 February 2018

Revised 27 January 2020

Accepted 30 January 2020

Keywords

God concept

indigenous psychology

integrated Islamic elementary

school

\begin{abstract}
Children at elementary schools have been able to develop their logical thinking and the ability to understand symbols and fundamental principles, yet still in a concrete fashion. Religion, however, introduces the concept of God, which is quite an abstract concept. Therefore, a learning method that can help children to develop their understanding of God is required. This research aimed to identify the conception of God on children enrolled in Integrated Islamic schools (SIT). The study used qualitative method with the indigenous psychology approach. The study collected data from 200 students at Grade Six from Integrated Islamic elementary schools in Pekanbaru. The data was processed using thematic analysis based on the conception of God in Islamic tradition. The results showed that the majority of the respondents $(97.73 \%)$ described their conception of God with their understanding of God as the Creator (tawhid alrububiyya) involving the perfection of God, the willfulness of God, and the existence of God. The implementation of the understanding of God in daily life (tawhid al-uluhiyya) is then applied through prayers, compliance to religious rules, and submission toward God's commands. These results suggest that respondents comprehend the concept of God and implement such understanding through their daily activities.
\end{abstract}

\section{Introduction}

Childhood and teenhood are two complex periods in human life. During these periods, children and teenagers develop their conception of God. This development might affect their religious behaviors during their adulthood. Therefore, children and teenagers must get the necessary education on religion (Kirkpatrick in Verma, 2015). Wells (in Nelson, 2009) also stated that children have unique religious needs, different than the religious needs of adults. Based on research on children in India, Verma (2015) found that children from grades I-VIII show their curiosity and imagination about God. The children also has an ability to think, analyze, and express an abstract idea of God. Therefore the children questions can be very critical, such as questioning the process of creation of humankind and animals, questioning the existence of God, questioning the importance of religious activities, such as praying.

Such developments require attentive recognition from the adults around the children, especially concerning the development of their conception of God. The development of the concept of God is often considered as the most crucial part of the development of faith (De Roos, Iedema, \& Miedema, 2010). On children, the concept of God evolves alongside the development of their cognitive abilities. Children will build their conception of God based on 
the information they acquired of God and related issues. Thus, parents and carers need to answer children's critical questions with care (De Roos, Iedema, \& Miedema, 2010).

In order for children to develop their understanding of God, parents and carers need to stimulate children with the mental representation of the concept of God suitable for children such as by giving a descriptive explanation of God and also by giving affective and evaluative learning processes. Descriptive aspects of the learning process will lead children to comprehend the characteristics of God, such as what God looks like, where He resides, what $\mathrm{He}$ is capable of. The evaluative aspects of the learning process will guide children to appraise various events, be that positive or negative, and relate the events to the graciousness of God or His harsh judgment (Heller in De Roos, Iedema, \& Miedema, 2010).

A child's experience related to God will not influence the child's understanding of religion only but also has a significant impact on the development of the child's psychological well-being during adulthood. This correlation is asserted by Van der Merwe, Van Eeden, \& Van Deventer (2010) on their research focusing on second and third generations of Christians. This research showed that someone's understanding of the concept of God, their experience toward God-related affairs, and their comprehension of life determine their faith and affect their psychological well-being.

The development of the concept of God on children takes place in several stages in line with their cognitive abilities. During their elementary years, usually, when children are on their seventh to twelfth age, children attend schools that stimulate their intellectual abilities. However, during this developmental stage, a child's cognitive ability is still processing information concretely. A child is still unable to process advanced abstract concepts. Therefore, the conception of God possessed by children during this age period is usually also concrete and often anthropomorphic (Harms in Jannah \& Jazariyah, 2016). Some children might associate God with physical forms, such as a big person, or an elderly who lives on the high sky. Other children might imagine God with characteristics such as humans, with a face, hands, and feet. Nevertheless, some other children consider God as electricity or energy that enables everything to grow. The limited abstraction ability might also lead to children, when taught that God is Almighty, imagine that God is a giant with tremendous power (Paloutzian \& Park, 2005).

Research performed by De Roos, Iedema, \& Miedema (2010) to 165 pre-school children in the Netherland concluded that parents' and teachers' conceptualization of God affected the children's conceptualization of God. Parents influenced the relational components of the conceptualization of God to the children, while teachers influenced the conceptualization of God according to the holy books. Furthermore, the schools' position on religion also influenced the development of children's conceptualization of God.

Researches on the similar field have been conducted in Indonesia. Artanto (2006) conducted qualitative research, interviewing two respondents with the age period of ten to eleven years old. This research concluded that the children's imaginations and conceptualizations of God were the results of doctrines taught to them during lessons, both from parents and from teachers. Through the information given by parents and teachers, the children were building their concepts of God, who God is, and how God's graces work. The finding of this research highlighted the importance of parents and teachers in setting up the foundation of faith in children.

Subandi (2006) conducted theoretical research on various concepts of God that children may develop during their childhood. This research concluded that children's conceptualization of God started in the concrete description, then gradually gain abstraction along with their mental development. At some point during their developmental phase, children will start to conceptualize God in more abstract ways. Teachings influenced the children's ability to perceive abstract conceptualization of God, and other activities stimulated their abstraction ability. 
In Islamic tradition, the Qur'an teaches Muslims on the strategic role of parents in laying the foundation of faith to their children, such as in the sura Luqman (31) verse 13, which translated into: "And [mention, O Muhammad], when Luqman said to his son while he was instructing him, 'O my son, do not associate [anything] with Allah. Indeed, association [with him] is a great injustice." This Qur'anic message urges parents to take a proactive approach in teaching their children the foundation of faith. This position is similar to research that puts family as a center of faith and spiritual development (Boyatzis et al. in Nelson, 2009). D'Onofrio et al. (in Nelson, 2009) asserted that religiosity, religious affiliation, and religious practices are built upon the foundation laid by familial and communal interactions.

The importance of parents and teachers in laying the foundation of faith in a child reflects the importance of school and its curriculum toward the development of a child's religiosity. Integrated Islamic schools understand this concern and offer a curriculum that integrates Islamic traditions and the academic learning process. In an Integrated Islamic school, pupils are taught Islamic subjects such as the foundations of Islamic beliefs (aqida), Islamic characters ( $a k h l a q)$, and various religious practices such as reading the Qur'an. This approach attracts parents who prioritize religious education to their children.

Despite the wealth of research on children's developments, there is only limited research on children's conceptualization of God. The lack of a body of knowledge is even more prevalent when focusing on how students of Integrated Islamic elementary schools conceptualize God. Therefore, this research seeks to address the gap of knowledge by researching children's conceptualization of God on Integrated Islamic elementary schools' pupils. This research applied the indigenous psychological approach in order to observe children's conceptualization of God. An indigenous psychological approach is an approach combining content, such as meaning, values and faith, and contexts, such as family, culture, and ecology. The indigenous approach also emphasizes the efforts to attain a descriptive understanding of human functions within their social contexts (Kim, Yang, \& Hwang, 2010). These particular characteristics of the indigenous approach fit with the research's objective to understand the conceptualization of God on students of Integrated Islamic schools.

\section{Method}

This research employed a qualitative method using a "from within" indigenous psychological approach. Using this approach, the researchers observed internally developed theories and concepts. The indigenous information became essential, the primary source of information (Enriquez in Kim et al., 2010).

\section{Participants}

This research gathered data from Grade Six students from Integrated Islamic schools in Pekanbaru, Riau. Employing the cluster sampling method, this research gathered data from 200 students aged 10-11 years old. The data was gathered using an open-ended questionnaire, which allowed the participants to answer the questions freely without limitation. The question asked to the respondents was: "Could you tell me what you know about God?"

\section{Data analysis}

Collected data then analyzed with thematic analysis to identify, analyze, and report patterns or themes gathered from a data set. Refer to Braun \& Clarke (2012), six stages of thematic analysis were conducted. First, the data preparation stage. During this stage, the researchers read and built up preliminary notes based on ideas and themes found in the data set. Second, the coding stage. In order to further analyze the data, the researchers set a category of codes and assigned information acquired from the data set to the code category. Third, classified the codes into relevant themes. Fourth, categorization of the themes into clusters for further 
association. Fifth, analyzed the clusters of themes to understand the specific characteristics of each cluster better, put labels to the clusters, and developed a definition for each cluster. Sixth, the final analysis stage. During this stage, the researchers selected specific examples from the clusters, extracted relevant information, and connected it to the research question and literature review. The researchers then processed any necessary responses written by respondents into data for further multi-response analysis.

\section{Results}

Based on the thematic analysis performed to the data set, the researchers found 926 variances of responses from the respondents. These responses could be categorized into two clusters: the understanding of God, in Islamic terminology, is known as tawhid al-rububiyya, and the implementation of the understanding on God, or tawhid al-uluhiyya in Islamic vocabulary. The result of the categorization of the data is shown in Table 1.

Table 1

Categorization of Conception of God

\begin{tabular}{llr}
\hline \multicolumn{1}{c}{ Category } & \multicolumn{1}{c}{ Sub-category } & Frequency \\
\hline Understanding God as the Creator (tawhid al-rububiyya) & The perfection of God & 468 \\
& The existence of God & 97 \\
& The willfulness of God & 340 \\
Implementing the understanding of God (tawhid al-uluhiyya) & Hoping to God & 1 \\
& Performing religious rituals & 9 \\
& Obeying God's commands & 9 \\
& Submission to God's will & 926 \\
\hline \multirow{2}{*}{ Total } & & \\
\hline
\end{tabular}

Table 1 shows that the majority of responses $(97.73 \%)$ could be grouped into the understanding of God as the Creator, with sub-categories within this group as follow: the perfection of God, the existence of God, and the willfulness of God. These three subcategories are known in Islamic traditions as part of tawhid al-rububiyya.

Table 2

Variances on the Perfection of God

\begin{tabular}{lrrrrr}
\hline \multicolumn{1}{c}{ Sub-category } & Frequency & Percentage & Sub-category & Frequency & Percentage \\
\hline The One & 174 & $37.18 \%$ & The Most Kind & 6 & $1.28 \%$ \\
The Most Merciful & 50 & $10.68 \%$ & The Sustainer & 6 & $1.28 \%$ \\
The Almighty & 40 & $8.55 \%$ & The Most Wise & 6 & $1.28 \%$ \\
The Most Compassionate & 39 & $8.33 \%$ & The Ever-forgiving & 6 & $1.28 \%$ \\
The All-Knowing & 30 & $6.41 \%$ & The Majestic & 4 & $.85 \%$ \\
The All-Seeing & 25 & $5.34 \%$ & The Giver of Life & 3 & $.64 \%$ \\
The Ever-giving & 13 & $2.78 \%$ & The Noble & 3 & $.64 \%$ \\
The Creator & 13 & $2.78 \%$ & The Protector & 2 & $.43 \%$ \\
The Utterly Just & 12 & $2.56 \%$ & The Helper & 1 & $.21 \%$ \\
The Forgiver & 11 & $2.35 \%$ & The Most Holy & 1 & $.21 \%$ \\
The All-Hearing & 11 & $2.35 \%$ & The Receiver of & 1 & $.21 \%$ \\
The Greatest & 10 & $2.14 \%$ & The All Rich & 1 & $.21 \%$ \\
\hline
\end{tabular}


Further analysis of the data set showed that there are variances in describing the perfection of God, as shown in Table 2. On the total, there are 24 variances on the perfection of God. The top five are the One (37.18\%), the Most Merciful $(10.68 \%)$, the Almighty (8.55\%), the Most Compassionate (8.33\%), and the All-Knowing (6.41\%).

Table 3 shows the variance in the respondents' conception of the existence of God. There are two dominant sub-categories: different than the creation $(47.42 \%)$ and everlasting $(11.34 \%)$.

Table 3

Variance on the Existence of God

\begin{tabular}{lrrlrr}
\hline \multicolumn{1}{c}{ Sub-category } & Frequency & Percentage & Sub-category & Frequency & Percentage \\
\hline Different than creation & 46 & $47.42 \%$ & Manifest & 3 & $3.09 \%$ \\
Everlasting & 11 & $11.34 \%$ & The First & 2 & $2.06 \%$ \\
Position & 8 & $8.25 \%$ & Not allowed to imagine & 2 & $2.06 \%$ \\
God for all creation & 6 & $6.19 \%$ & Zat & 1 & $1.03 \%$ \\
The Bestower of prayers & 5 & $5.15 \%$ & Beautiful & 1 & $1.03 \%$ \\
Nobody knows & 3 & $3.09 \%$ & All-Present & 1 & $1.03 \%$ \\
The Owner & 3 & $3.09 \%$ & Has face & 1 & $1.03 \%$ \\
The King & 3 & $3.09 \%$ & All-Knowing & 1 & $1.03 \%$ \\
\hline
\end{tabular}

Table 4 shows the variance in describing the willfulness of God. Two answers dominated this category: The Creator (68.82\%) and the Bestower of Good (17.65\%).

Table 4

Variance on the Willfulness of God

\begin{tabular}{clrr}
\hline No. & \multicolumn{1}{r}{ Sub-category } & Frequency & Percentage \\
\hline 1 & The Creator & 234 & $68.82 \%$ \\
2 & The Bestower of Good & 60 & $17.65 \%$ \\
3 & The Commander & 16 & $4.71 \%$ \\
4 & The Sustainer & 13 & $3.82 \%$ \\
5 & The Guide & 6 & $1.76 \%$ \\
6 & The Bestower of prayers & 4 & $1.18 \%$ \\
7 & The Avenger & 3 & $.88 \%$ \\
8 & The Nourisher & 3 & $.88 \%$ \\
9 & The Forgiver & 1 & $.29 \%$ \\
& & 340 & $100.00 \%$ \\
\hline
\end{tabular}

Table 5 shows the variance of the respondents' conceptualization on the implementation of their understanding in God. There are two dominant responses: obeying God's commands (42.87\%) and performing religious rituals $(42.85 \%)$. 
Table 5

Categories on Implementation on the Understanding of God

\begin{tabular}{|c|c|c|c|c|}
\hline No. & Sub-category & & Frequency & Percentage \\
\hline \multirow[t]{3}{*}{1} & Performing religious rituals & Worshipping God & 6 & $28.57 \%$ \\
\hline & & Praying & 2 & $9.52 \%$ \\
\hline & & Effort & 1 & $4.76 \%$ \\
\hline \multirow[t]{3}{*}{2} & Obeying God's command & Having faith in God & 3 & $14.29 \%$ \\
\hline & & Obey & 3 & $14.29 \%$ \\
\hline & & Conscious of God & 3 & $14.29 \%$ \\
\hline 3 & Submission to God's will & Submission & 2 & $9.52 \%$ \\
\hline \multirow[t]{2}{*}{4} & Hoping & Depending on God & 1 & $4.76 \%$ \\
\hline & \multicolumn{2}{|c|}{ Total } & 21 & $100.00 \%$ \\
\hline
\end{tabular}

\section{Discussion}

The result of this research shows that the students of Integrated Islamic schools maintained a conceptualization of God described in the form of understanding God as the Creator and implemented in their daily activities. As discussed previously, children's conceptualization of God is the result of processing and combining various separated images related to God (Hurlock, 2008). As a monotheistic religion, Islam directs believers to understand God as One. This understanding of God in Islamic vocabulary is known as tawhid or the Oneness of God.

In Islamic traditions, tawhid is of utmost importance. Islam sees tawhid as part of the fitra, the essential natural condition bestowed from God to humankind. Tawhid is the core teaching of Islam and had become the central message of all prophets and messengers of Islam. Within Islamic traditions, prophets from Adam to Moses, Jesus, and Muhammad, all brought the message of tawhid despite differences in religious rituals. There are two types of tawhid in Islam: tawhid al-rububiyya, which is a set of belief concerning the characteristics of God, portrayed in God's holy names, and tawhid al-uluhiyya or also known as tawhid alibada, which is the act of submission and compliance toward God's commands through performing religious rituals (Ath-Thahawiy, 2006).

Tawhid al-rububiyya directs humans to know and understand God from His characteristics, names, and deeds. Characteristics imply the perfectness of God, the different statuses, and traits that God has compared to humans and other creations. Af'al is God's deeds that illustrate His Will toward the creation, such as creating, testing, healing, managing the nature, resurrecting the dead, and many more. Asma' is God's 99 holy names that define His perfect characteristics (Ath-Thahawiy, 2006). In the Islamic tradition, understanding the tawhid al-rububiyya indicates a Muslim's understanding that there is no god but God, the Oneness of God, and His absolute wills and commands. God is the one and only Creator, the Sustainer, and the Provider for all creations (Faleemu \& Raheem in Ezenweke \& Onyedinma, 2013).

The implementation of Islamic faith in daily life denotes the concept of tawhid aluluhiyya. Tawhid al-uluhiyya is the act of total surrender, complete submission, and unyielding obedience toward God's wills and commands. The foundation of tawhid aluluhiyya is that Muslims worship only God without associating other being or power into His Position. God is the only source of hope and love, the only destination for prayers and expectations. Every endeavor a Muslim does will find its conclusion on God's mercy (Faleemu \& Raheem in Ezenweke \& Onyedinma, 2013). 
Using their understanding of tawhid al-uluhiyya, the students of Integrated Islamic schools could convey the concept by explaining the Oneness of God and that following God's commands is the ultimate duty of humankind. The students were able to explain that they felt hopeful of God's mercy. They believed that God the Merciful and Redeemer would abolish their sins and granted them the paradise (Faleemu \& Raheem in Ezenweke \& Onyedinma, 2013).

The research shows that the majority of the respondents (97.73\%) described God in the context of tawhid al-rububiyya, while the rest (2.27\%) described God in the context of tawhid al-uluhiyya. Further analysis shows that form 926 respondents, 234 respondents portrayed God as possessing the will to create. Consequently, the respondents believed that God was the creator of the universe, including humankind, animals, and vegetations. The respondents also believed that God had sent the prophets to guide humankind toward His blessings. There are 174 respondents who described the perfection of God as the One, the only God without any allies or associations. These results showed that the students from Integrated Islamic schools had been able to understand the concept of God as the creator of the universe.

The respondents had a positive conceptualization toward God, naming God as the Most Merciful, the Most Compassionate, the Almighty, the All-Knowing, and the Bestower of Good. The positive conceptualization is essential because a positive conceptualization will stimulate the development of positive mental attitude and positive emotional development in the children's minds. It then would encourage a positive attitude to religion, such as acceptance and seeking out religious experiences. If the conceptualization had been full of negative imageries, it would prompt the children toward negative attitudes to religion, such as antagonism and avoidance (Hurlock, 2008). In Islamic tradition, if a child conceptualizes God as the Most Merciful and Most Compassionate, this conceptualization will appeal to the child and develop a comforting relationship between the child and God. The child will have the opportunity to develop a better religious experience compared to other children that develop the concept of God as the cruel and punishing god.

The study indicates that while the respondents were 10-11 years old, their conceptualization of God had been on individualistic stage, commonly prevalent on 13-18 years old children. On the individualistic stage, God is conceptualized according to formalized religious traditions followed by people around them, usually mystical and symbolical in nature (Harms in Jannah \& Jazariyah, 2016). In this study, responses such as "God is the protector against all problems," "God is All-Knowing the hearts of humans," "God is without spouse and children," indicated the individualistic understanding of God conforming to the formalized Islamic traditions. From all respondents, $47.42 \%$ described God as "different from the creation," and $11.34 \%$ described God as "everlasting." There was only a small portion of the respondents describing a more anthropomorphic conceptualization of God, such as "God is like a king" or "God is sitting on His Throne."

The respondents' conceptualization of God is illustrating their cognitive development. This study observed that most of the respondents had been able to conceptualize God in abstract definitions, which indicated that the respondents' cognitive development had reached the formal operational stage. During this formal operational stage, a child has acquired abstraction thinking skills, able to convey complex abstract thinking, and propose a hypothesis. The variance of responses such as "God is the Most Perfect" or "God exists differently than humans" reflects the level of abstraction that the respondents had developed. Only a minor portion of the respondents conceptualized God as "a creator," "a noble person," or "a kind person."

The result of this study is in line with other research, such as the work of Elkind (in Hood, Hill, \& Spilka, 2009), which argued that children are unable to understand the abstract concepts in a religion before they reach 11-12 years old, the age period marking the beginning of the formal operational stage according to Piaget. Children during this age period will start 
to understand the complexities of religious rituals and practices and might undergo religious conversion. Other research explaining similar information is Verma (2015), which concludes that children will develop their understanding of religion following the development of their cognitive abilities. Thus there are three distinct age groups concerning children's understanding of religion: 5-8 years old, 9-10 years old, and 11-13 years old. Younger children tend to express their understanding of religion concretely while older children might able to express it more abstractly.

This research indicates that 10-11 years old children have the ability to understand religion in an elaborate manner. Not only building their understanding on the etymological level, which deals with understanding God as a 'theoretical construct,' but also able to understand religion in the practical level. This ability, in Islamic traditions, is of utmost importance since the application of faith (tawhid al-uluhiyya) is the logical consequence of someone's understanding in God (tawhid al-rububiyya). Thus, a Muslim should not only declaring his or her faith in God but also needs to implement such faith in their daily activities.

Within Integrated Islamic schools, religious education is considered essential. The schools do not introduce religious concepts to the pupils in the classroom but also in daily activities through the leadership of the teachers. The schools allocate special sessions for religious activities such as morning prayers, Qur'an recitations, and other rituals. The schools also utilize the thematic learning curriculum to teach Islamic worldview on the topics and to teach Islamic virtues to the pupils. The integration of religion and academic activities is prevalent in Integrated Islamic schools, thus creating a comprehensive Islamic learning environment for the students.

Artanto (2006) asserted that other than family, several social factors can influence a person's religiosity: education, opinion, and activities from the nearby social environment and accepted traditions. Reflecting Thouless's assertion to the learning environment managed by Integrated Islamic schools, this research argues that the Islamic learning environment carefully constructed by Integrated Islamic schools stimulate and accelerate the development of religious understanding in the schools' students. Integrated Islamic schools' students are exposed to intense religious experience during their school time and then internalize the experience into a personal religious conviction. This specific learning environment might explain why the respondents had been able to reach a more mature understanding of the conceptualization of God, compared to their age period.

Since this research focuses on students of Integrated Islamic schools, generalization should be considered in caution. The results described in this research might apply only to schools within the Integrated Islamic schools network, or schools implemented a similar learning model. Future studies should broaden the scope of the study by collecting responses from students of schools implementing different learning models, such as state schools or religious schools (madrasa ibtidaiyya). Future studies also might find insight by collecting responses from students of lower age periods, thus able to gain a richer data set compared to this research.

\section{Conclusion}

The result of this study shows that the students developed their conceptualization of God into two categories: first, the understanding of God's nature and characteristics, also known in Islamic vocabulary as tawhid al-rububiyya, and second, the understanding that the understanding in God should congeal in religious rituals such as daily prayers, known in Islamic vocabulary as tawhid al-uluhiyya. Respondents' description of God's nature and characteristics showed that the respondents' understood God's position as the Creator, God is the One, with no association, and that God has 99 holy names defining His characteristics. Respondents were able to distinguish God from creation, stressing on God's perfection, and 
everlasting characteristic. Respondents then further describe their understanding of the consequences of such understanding, such as by stating that humans' activities should focus on obtaining God's mercy that humans should submit to God's wills, and comply with God's commands. These implies that students of Integrated Islamic schools understand religion in a complicated way, they are able to translating the abstract construct of God into the practical application level.

\section{References}

Artanto, D. R. (2006). Konsep Tuhan pada anak usia akhir operasional konkret (The concept of God among children in concrete operational stage). Psikologika, 11(21), 5-21. https://doi.org/10.20885/psikologika.vol11.iss21.art1

Ath-Thahawiy, A. J. (2006). Al-Aqidah Ath-Thahawiyyah. Kairo: Dar Al-Ghad Al-Jadid.

Braun, V., \& Clarke, V. (2012). Thematic analysis. In H. Cooper, P. M. Camic, D. L. Long, A. T. Panter, D. Rindskopf, \& K. J. Sher (Eds.), APA handbooks in psychology®. APA handbook of research methods in psychology, Vol 2. Research designs: Quantitative, qualitative, neuropsychological, and biological (pp. 57-71). American Psychological Association. https://doi.org/10.1037/13620-004

De Roos, S. A., Iedema, J., \& Miedema, S. (2010). Young children's descriptions of God: Influences of parents' and teachers' God concepts and religious denomination of schools. Journal of Beliefs \& Values, 22(1), 19-30. https://doi.org/10.1080/13617670123273

Ezenweke, E. O. (2013). Whose God is God? Exploring the concept of God within religions. London: Adonis \& Abbey Publishers Ltd.

Hood, R. W., Hill, P. C., \& Spilka, B. (2009). The psychology of religion: An empirical approach. New York: The Guilford Press.

Hurlock, E. B. (2008). Psikologi perkembangan, suatu pendekatan sepanjang rentang kehidupan (Developmental psychology: A life span approcah). Jakarta: Erlangga.

Jannah, R. R., \& Jazariyah. (2016). Internalisasi Nilai-nilai Agama pada Anak Usia Dini Melalui Redesain Mesjid Besar Jatinom Klaten (Internalisation of religion values on early childhood though redesign Jatinom great mosque). Jurnal Pendidikan Anak AlAthfal, 2(1), 15-28.

Kim, U., Yang, K., \& Hwang, K. (2010). Indigenous and cultural psychology, memahami orang dalam konteksnya (Indigenous and cultural psychology: Understanding people in their context). Yogyakarta: Pustaka Pelajar.

Nelson, J. M. (2009). Psychology, religion, and spirituality. USA: Springer.

Paloutzian, R. F., \& Park, C. L. (2005). Handbook of the psychology of religion and spirituality. New York: The Guilford Press.

Subandi. (2006). Konsep anak tentang Tuhan (Children's concept of God). Psikologika, 11(21), 22-26. https://doi.org/10.20885/psikologika.vol11.iss21.art2

Van der Merwe, K., Van Eeden, C., \& Van Deventer, H. J. M. (2010). A psychological perspective on god-belief as a source of well-being and meaning. HTS Teologiese Studies / Theological Studies, 66(1), 1-10. https://doi.org/10.4102/hts.v66i1.332

Verma, M. R. (2015). A comparative study of childrenes conception of God on the basis of age/grades. Asian Journal of Multidisciplinary Studies, 3(6), 138-155. 